\title{
SSR-based tool for identification and certification of commercial Populus clones in Spain
}

\author{
Ana I. DE-Lucas*, José C. SANTANA, Patricia Recio, Elena Hidalgo \\ Departamento de Producción Vegetal y Recursos Forestales, E.T.S., Ingenierías Agrarias, Universidad de Valladolid, Avenida de Madrid 44, \\ 34004 Palencia, Spain
}

(Received 6 November 2006; accepted 3 October 2007)

\begin{abstract}
In order to protect the legitimate interests of the poplar breeders, growers and industries, we have developed a reliable and affordable certification tool for commercial poplars in Spain. We have carried out a genetic description of the 28 commercial clones of the current Spanish National Catalogue using 10 microsatellite molecular markers (SSR). The results clearly show that in the Spanish National Catalogue there are labelling mistakes including synonymies, supported by a combined probability of identity $(P I)$ of $1.18 \times 10^{-9}$. We have also demonstrate that it is possible to identify all the different clones (genotypes) with only three microsatellites, that show a combined probability of identity of $2.4 \times 10^{-4}$, and we have optimised the protocols to reduce the time and the economical costs of the analysis. This SSR-based tool could be incorporated in the current certification protocols, to avoid duplication of accessions and identification mistakes.
\end{abstract}

commercial poplar clone / microsatellite / identification / Spanish national catalogue

Résumé - Développement de marqueurs microsatellites pour l'identification et la certification des clones commerciaux de peuplier en Espagne. Dans le but de protéger les intérêts légitimes des cultivateurs, des sélectionneurs et des industriels de la populiculture, nous avons mis au point un outil de certification fiable et accessible pour les clones de peupliers commerciaux en Espagne. Nous avons fait une description génétique des 28 clones commerciaux de l'actuel catalogue national espagnol en utilisant 10 marqueurs moléculaires microsatellites (SSR). Les résultats obtenus indiquent clairement que ce catalogue contient des erreurs d'identification, dont des clones synonymes, soutenues par une probabilité combinée d'identité $(P I)$ de $1.18 \times 10^{-9}$. Nous avons également démontré qu'il est possible d'identifier tous les génotypes différents avec 3 microsatellites, qui montrent une probabilité combinée d'identité de $2.4 \times 10^{-4}$, et nous avons optimisé les protocoles afin de réduire le temps et le coût de l'analyse. Cet outil fondé sur les SSR pourrait être intégré dans les protocoles actuels de certification afin d'éviter la duplication des matériaux et les erreurs d'identification.

clone commercial de peuplier / microsatellite / identification / catalogue national espagnol

\section{INTRODUCTION}

The culture of poplar in the Iberian Peninsula has been continuously growing in the last decades, mainly due to its economic profitability. But it is also a response to the demand for quality poplar wood in Spain, and a relatively easy conversion of abandoned agriculture lands to forestry uses, a conversion promoted by the European Community within the CAP (Commune Agricultural Policy). According to the Spanish Poplar National Commission (http:// www.mapa.es/es/agricultura/pags/chopo/cortas.htm) and to the Agriculture Ministry (http://www.mapa.es/ es/estadistica/pags/encuestacultivos/resultados.htm), the harvested poplar wood has doubled in the last 25 years, reaching nearly $700000 \mathrm{~m}^{3}$ in 2005 with a total planted surface of 132167 ha. In this context of growing interest for poplar culture, many clones have been tested (see [17] and [19] for reviews), and several management manuals, adapted to the Spanish conditions have been written $[2,12,17,25]$. As a result of these tests, the National Catalogue including the

* Corresponding author: ailucas@pvs.uva.es poplar clones admitted in Spain was expanded in 2003 to 28 clones from only 14 in the previous Catalogue. Spanish laws establish that all the plant material for propagation purposes must be produced in authorised nurseries recorded in the "Registry of Plant Producers", to guarantee plant quality and clonal identity. The choice of a particular clone to be used in a given site combined with soil and climate conditions, and appropriate management techniques, determines the possible uses of the final harvested wood, its technical and industrial characteristics, and thus, its economic yield. In this context, an accurate identification of clones is essential, not only in propagation nurseries, but also in all the phases of poplar propagation and commercial exchanges. Traditionally, the clonal identity control and certification of plant material from nurseries is carried out by regional authorities on the basis of morphological or phenological descriptions and on floral characteristics [18]. Unfortunately, many of these characteristics are variable and depend on the age of the plants and on their sanitary conditions. Some characteristics are often subjective or unstable, as they are affected by environmental factors: soil and climate conditions, spacing and other management 
techniques. In addition, some of the important identification characteristics are not present in the one or two year-old plants coming from nurseries, and others refer to organs, such as leaves and flowers, that can only be observed in particular seasons. Therefore, the use of morphological features as the only criterion for clone identity control and certification is not advisable, because it can lead to mistakes that may not be detected for many years.

The difficulties in visual identification could be bypassed with the use of molecular markers-based tools, which are more reliable, stable and objective than morphological traits. A great amount of useful information for genetic characterization and identification of poplars has accumulated, coming from the use of both allozyme polymorphism $[28,30]$ or DNA markers: RAPDs [4, 23, 29, 31] AFLPs, [1, 6, 8, 15, 40], microsatellites (SSRs) [3, 6, 10, 14, 30] and ISSRs [20].

Compared to other molecular markers, SSRs are widely used for analysis of relationships between individuals, genetic variability and divergence among natural populations of numerous species (e.g. $[13,16,32])$. They are also the most useful tool for the genetic characterization of plant material, due to their particular genetic traits: high degree of polymorphism, codominance, high reproducibility, transferability between related species and relatively low implementation costs. Also, their resolution capacity and their stability are greater than those of allozymes and RAPDs, and their technical complexity and economic costs are lower than those of high efficiency markers such as AFLPs or SAMPLs. The main restriction for their use is that microsatellite loci have to be detected and sequenced to promote specific amplification, and that their polymorphism has to be tested in each sample set.

In the last decade, several authors have designed specific SSR primers for particular Populus species: for $P$. tremuloides, [9, 27]; for $P$. nigra, [33, 37]; and for $P$. trichocarpa [36], most of them available at Poplar Molecular Genetics Cooperative data base (http://www.ornl.gov/sci/ipgc/ssr_resource.htm). As many of them have shown their usefulness on different poplar species or hybrids, it is advisable to use them for the molecular description of commercial poplars, most of which are interspecific hybrids $[3,15,29,40]$.

To protect the legitimate interests of the poplar breeders, growers and industries, we have developed a reliable and affordable certification tool for commercial poplars in Spain. For this purpose, we have carried out a complete genetic description of the 28 commercial clones of the current Spanish Catalogue, to establish their genotypes. In addition, we have optimised the protocols to reduce the time and the economic costs of analysis.

\section{MATERIALS AND METHODS}

\subsection{Plant material}

The 28 registered poplar clones of the Spanish National Catalogue (Tab. I) used in this study were provided by five nurseries belonging to the "Registry of Plant Producers" of Spain: (i) Servicio
Table I. List of the commercial clones analyzed in this study.

\begin{tabular}{|c|c|c|c|}
\hline Species & $\begin{array}{l}\text { Name of } \\
\text { the clone }\end{array}$ & $\begin{array}{c}\text { No. } \\
\text { ramets }\end{array}$ & Provider \\
\hline \multirow[t]{17}{*}{$P . \times$ euramericana } & Agathe F. & 10 & ZA, GU, GE, LE \\
\hline & Campeador & 9 & ZA, GU, GE, LE \\
\hline & Canada Blanco & 9 & ZA, GU, GE, LE \\
\hline & Flevo & 9 & ZA, GU, GE, LE \\
\hline & I-MC & 9 & ZA, GU, GE, LE \\
\hline & $\mathrm{I}-214$ & 9 & ZA, GU, GE, LE \\
\hline & $\mathrm{I}-488$ & 6 & ZA, GU, GE \\
\hline & Luisa Avanzo & 9 & ZA, GU, GE, LE \\
\hline & Triplo & 9 & ZA, GU, GE, LE \\
\hline & 2000 Verde & 8 & ZA, GU, LE, M \\
\hline & B-1M & 7 & ZA, GU, LE \\
\hline & BL-Costanzo & 4 & $\mathrm{ZA}, \mathrm{GU}$ \\
\hline & Branagesi & 7 & ZA, GU, LE \\
\hline & Dorskamp & 7 & ZA, GU, LE \\
\hline & Guardi & 10 & ZA, GU, LE, M \\
\hline & $\mathrm{I}-454 / 40$ & 7 & ZA, GU, LE \\
\hline & NNDv & 7 & ZA, GU, LE \\
\hline P. deltoides $\times$ P. alba & I-114/69 & 6 & ZA, GU, GE \\
\hline \multirow[t]{2}{*}{ Populus deltoides } & Lux & 6 & ZA, GU, GE \\
\hline & Viriato & 6 & ZA, GU, LE, M \\
\hline \multirow[t]{3}{*}{ Populus nigra } & $\operatorname{Tr} 56 / 75$ & 9 & ZA, GU, GE, LE \\
\hline & Bordils & 8 & ZA, GU, GE, LE \\
\hline & Lombardo Leonés & 4 & GU, LE \\
\hline \multirow[t]{5}{*}{$P . \times$ interamericana } & Beaupré & 9 & ZA, GU, GE, LE \\
\hline & Raspalje & 9 & ZA, GU, GE, LE \\
\hline & Boleare & 8 & ZA, GU, LE \\
\hline & Unal & 7 & ZA, GU, LE \\
\hline & USA 49-177 & 5 & GU, LE \\
\hline TOTAL & 28 & 213 & \\
\hline
\end{tabular}

ZA: Servicio de Investigación Agraria de la Diputación General de Aragón (SIA-DGA); GU: Centro Nacional de Mejora Forestal de "El Serranillo" (MIMAM); GE: Estación experimental "Mas Badía" (IRTADARP); LE: Vivero de chopo de la Junta de Castilla y León (Villafer, León); M: Vivero del Centro de Investigaciones Forestales del Instituto Nacional de Investigación Agraria (CIFOR-INIA) (Madrid).

de Investigación Agraria de la Diputación General de Aragón (SIADGA); (ii) Centro Nacional de Mejora Forestal de "El Serranillo" (MIMAM); (iii) Estación experimental "Mas Badía" (IRTA-DARP); (iv) Vivero de chopo de la Junta de Castilla y León (Villafer, León) (v) Vivero del Centro de Investigaciones Forestales del Instituto Nacional de Investigación Agraria (CIFOR-INIA) (Madrid).

Young leaves and wood from poplar trees were harvested, carefully labelled and lyophilised $\left(24 \mathrm{~h},-40^{\circ} \mathrm{C}\right)$ from all five cited nurseries, taking samples from every clone present at each nursery. Lyophilised plant material was stored at $-80{ }^{\circ} \mathrm{C}$ until DNA extraction. 


\subsection{DNA extraction and SSR analysis}

After crushing lyophilised plant material in a Mixer Mill 301 (Reetsch $\mathrm{GmbH} \& \mathrm{Co}$, Haan, Germany) $(30 \mathrm{~Hz}, 45 \mathrm{~min}$ for wood samples; or $30 \mathrm{~Hz}, 10 \mathrm{~min}$ for leaves), total genomic DNA was isolated following the protocol by Doyle and Doyle [11] modified by Torres et al. [35] for small volumes. Ten nuclear microsatellite regions were selected considering genetic independence between markers and assuming the good synteny already described among Populus species [6]. Moreover, five of them are those used in the previous work of Fossati et al. [15], which will allow us to compare the results obtained. The SSR loci used and corresponding linkage groups (LG) were the following: PTR2 (LG IX), PTR4 (LG III) [9] and PTR7 (LG XII) [27] developed for P. tremuloides; WPMS9 (LG VI), WPMS14 (LG V), WPMS16 (LG VII), WPMS18 (LG not found), WPMS20 (LG not found) developed for P. nigra [33, 37]; PMGC14 (LG XIII) and ORPM127 (LG IV) developed for P. trichocarpa [36]. The forward primer for each locus was previously labelled with one of the three fluorochromes: 6-FAM, HEX or NED (Applied Biosystems, Foster City, Ca, USA), and a common fluorochrome label for different SSR markers was chosen for nonoverlapping allele ranges.

To reduce the costs of the analysis, several multiplex reactions and lower reaction volumes were assayed with different primer combinations. Initial reaction volumes and amplification conditions were described by the following authors: for PTR2 and PTR4, Dayanandan et al. [9]; for PTR7, Rahman et al. [27]; for WPMS14, WPMS16, WPMS18 and WPMS20, Smulders et al. [33]; for WPMS9, Van der Schoot et al. [37]; for PMGC14, Tabbener et al. [34]; and for ORPM127, Tuskan et al. [36]. In all cases, we used a GeneAmp 9700 thermal cycler (Applied Biosystems) and the amplified fragments were analysed in an ABI-PRISM 310 genetic analyser (Applied Biosystems) using GeneScan ROX-500 as the internal standard. The sizing of the amplified fragments was carried out by GeneScan v.3.7. software (Applied Biosystems), which provides a raw result for the length fragment with two decimals of b.p. These results can vary somewhat ( \pm 1 nucleotide) in different machines, gels or capillary electrophoretic runs, while keeping the relative distances of alleles, and thus permitting the absolute identification of the clones.

\subsection{Allele binning and data analysis}

In order to obtain consistent results, each DNA was extracted, amplified and analysed for each locus, at least, two completely independent times for each sample. The allele binning was carried out using all the fragment sizes obtained in all the samples and all the repetitions analysed. Two approaches were used: frequency histograms for each marker and the plotting technique [22] based in sorted allele sizes.

The parameters calculated in order to evaluate the amount of information given by each locus were: the expected heterozygosity $\left(H_{e}\right.$; [24]), the observed heterozygosity $\left(H_{o}\right)$, the number of alleles for each locus, the probability of identity $(P I ;[26])$ and the paternity exclusion probability ( $P E ;[39])$. We also calculated the probability of identity and paternity exclusion probability combined over all loci. These statistical parameters were calculated with the program IDENTITY 1.0 [38]. Moreover, to estimate the discriminatory power of each locus we considered the number of observed genotypes and the number of clones with unique genotypes. The relationships among the commercial poplar clones in the Spanish National Catalogue were illustrated by a phylogenetic tree based on unrooted neighbor-joining $(N J)$ method using Cavalli-Sforza chord distance $D_{C}$ [5]. This dendrogram was generated using POPULATIONS software [21].

\section{RESULTS}

\subsection{Genetic description of the 28 commercial clones of the Spanish National Catalogue}

Ten SSR markers were used on the 28 commercial clones of Spanish National Catalogue, and their genotypes were determined from their allelic combined constitution. All the markers used yielded consistent amplification products, and, in all cases, the completely independent samples (ramets) analysed from each nursery showed the same results. Only PTR4 on the $P . \times$ interamericana did not amplify. All the analysed loci were polymorphic for this set of samples, ranging from 4 (PTR4) to 18 (WPMS14) alleles with an average of 9.6 alleles per marker (Tab. II). Regarding the observed and unique genotypes, the most informative loci were ORPM127 and WPMS14, with values greatly above the average for these two parameters. In fact, ORPM127 and WPMS14 SSR markers allow for the identification of 16 and 15 out of the 28 clones of the Spanish National Catalogue, respectively. The expected and observed heterozygosity ranged from 0.53 to 0.89 and from 0.04 to 0.93 , respectively, with PTR4 giving the lowest and WPMS14 the highest allelic diversity values.

In order to evaluate the identification capacity of each locus, the probability of identical genotypes $(P I)$ was calculated. The lowest $P I$ value (0.04), corresponding to highest paternity exclusion probability values, was observed for three SSRs: PTR7, WPMS14 and ORPM127. The combined probability for identical genotypes calculated for all the markers together was $1.18 \times 10^{-9}$ and the total exclusion probability reached a value of 0.99 . Among the 28 different clones listed in the Spanish National Catalogue, only 26 different combined genotypes were detected (Tab. III). Two sets of clones [I-214/Campeador] and [I-MC/NNDv/BL-Costanzo] showed identical genotypes for the ten microsatellites assayed. Besides, we also found two different genotypes within the samples labelled as "Bordils" from different nurseries (in eight out of ten loci), both of them unique within the Spanish National Catalogue. They are identified henceforth as "Bordils" " and "Bordils". In addition, several problems of nursery identification were detected in the following clones: (i) Some of the samples collected under the name "Viriato" in one of the registered nurseries showed the combined genotype specific for "Triplo" (identified henceforth as "Viriato" "). (ii) The samples labelled as "2000 Verde" and "Guardi" from one of the official nurseries showed crossed genotypes based on the results from all the other nurseries.

The neighbor-joining unrooted $(N J)$ phylogenetic tree of Figure 1. show the genetic relations between the clones analysed. All clones appear cluster by species and there is a good correlation to morphological characteristics. Only Flevo clone, which has been reported to have morphological features similar to P. nigra comes out among this group of clones (J. Rueda, personal communication). 
Table II. Genetic parameters from the microsatellite DNA loci observed for the 28 commercial clones of this study.

\begin{tabular}{|c|c|c|c|c|c|c|c|c|}
\hline Locus & $H_{e}$ & $H_{o}$ & $\begin{array}{c}\text { No. } \\
\text { alleles }\end{array}$ & $\begin{array}{c}\text { No. } \\
\text { observed } \\
\text { genotypes }\end{array}$ & $\begin{array}{l}\text { No. clones } \\
\text { with unique } \\
\text { genotype }\end{array}$ & $P I$ & $P E$ & $\begin{array}{c}\text { Allelic range } \\
\text { (p.b.) }\end{array}$ \\
\hline PTR 2 & 0.66 & 0.67 & 7 & 9 & 3 & 0.27 & 0.41 & $203-221$ \\
\hline PTR 4 & 0.53 & 0.04 & 4 & 3 & 1 & 0.53 & 0.23 & 195-203 \\
\hline PTR 7 & 0.89 & 0.20 & 11 & 13 & 5 & 0.04 & 0.78 & $227-253$ \\
\hline WPMS 14 & 0.89 & 0.93 & 18 & 20 & 15 & 0.04 & 0.78 & $221-278$ \\
\hline WPMS 16 & 0.76 & 0.90 & 7 & 12 & 3 & 0.17 & 0.55 & $127-166$ \\
\hline WPMS 18 & 0.62 & 0.67 & 8 & 11 & 6 & 0.24 & 0.41 & $215-248$ \\
\hline WPMS 9 & 0.81 & 0.63 & 10 & 13 & 8 & 0.11 & 0.11 & $232-282$ \\
\hline PMGC 14 & 0.82 & 0.90 & 9 & 14 & 7 & 0.10 & 0.66 & $190-223$ \\
\hline WPMS 20 & 0.62 & 0.73 & 6 & 8 & 3 & 0.32 & 0.37 & $214-238$ \\
\hline ORPM 127 & 0.89 & 0.90 & 16 & 21 & 16 & 0.04 & 0.79 & $156-226$ \\
\hline Mean & 0.75 & 0.66 & 9.6 & 12.4 & 6.7 & 0.18 & 0.51 & - \\
\hline
\end{tabular}

Genetic parameters: expected and observed heterozygosity $\left(H_{e}\right.$ and $\left.H_{o}\right)$, number of alleles, number of observed genotypes, number of clones with unique genotype, probability of identity $(P I)$, paternity exclusion probability $(P E)$ and allelic range in base pairs.

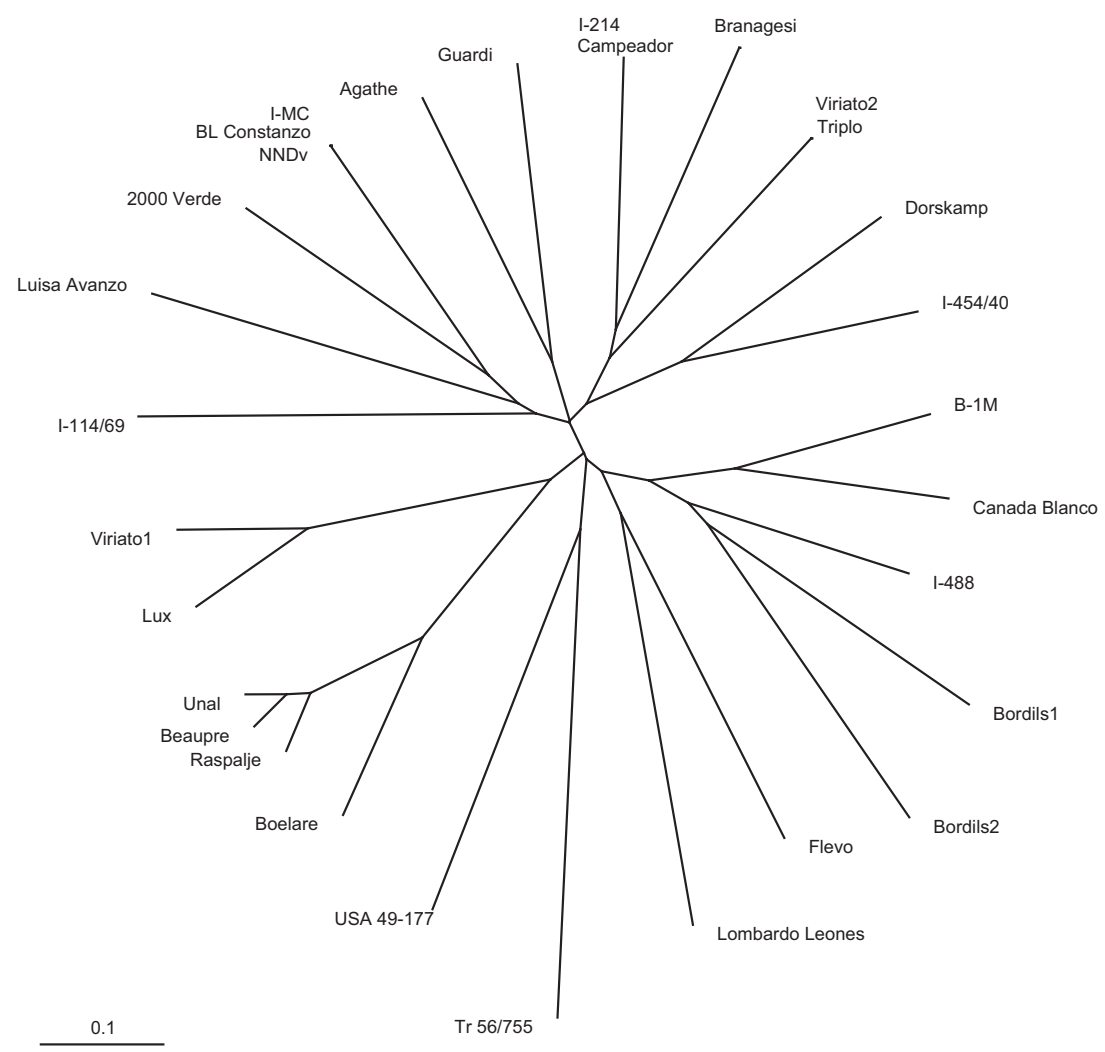

Figure 1. Neighbor-joining unrooted $(N J)$ phylogenetic tree of the 28 commercial poplar clones registered in the Spanish National Catalogue constructed using Cavalli-Sforza chord distance $\left(D_{C}\right)$. 
|ป่

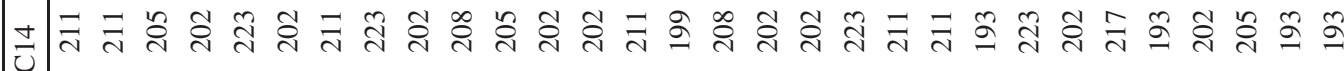

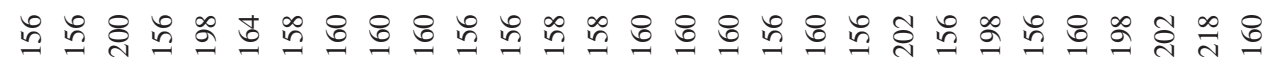

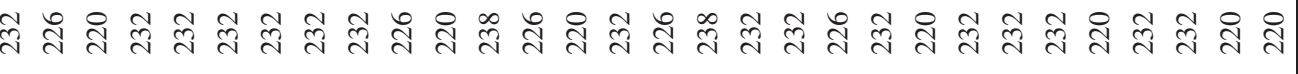

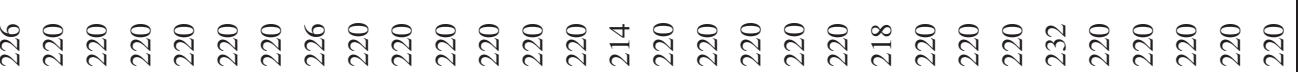

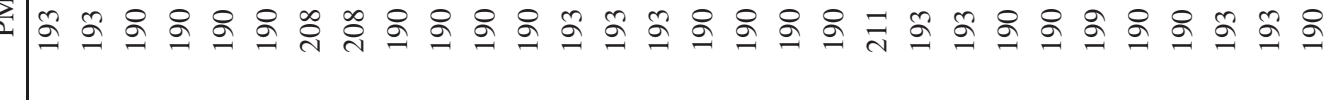

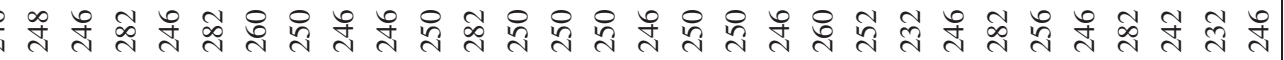

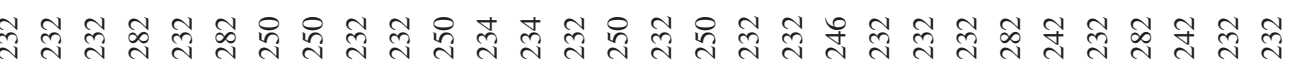
舟

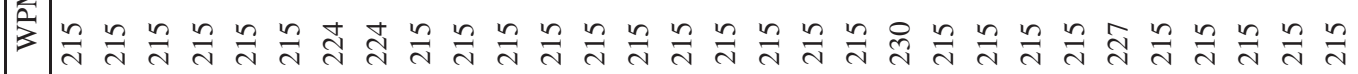

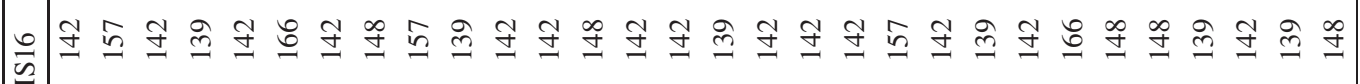

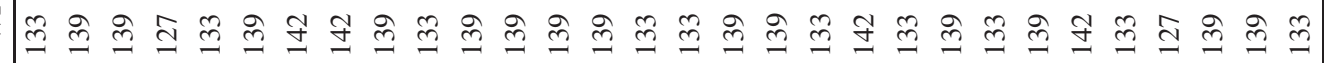

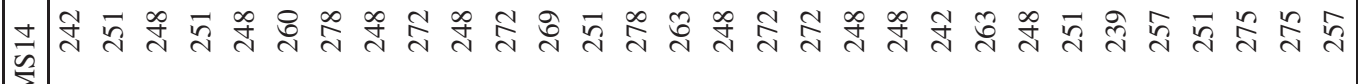

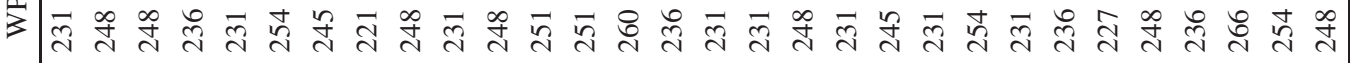

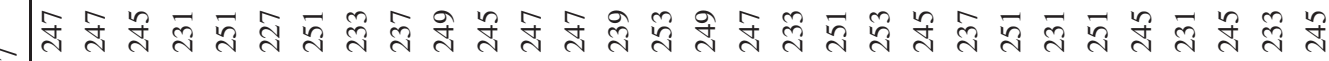
先

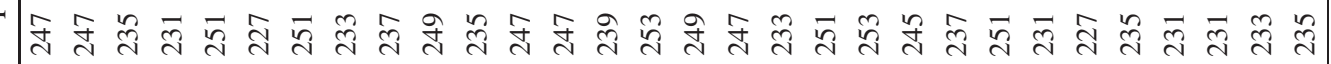

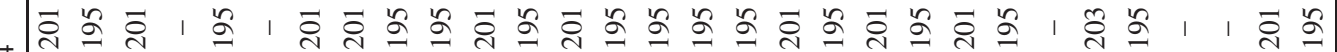

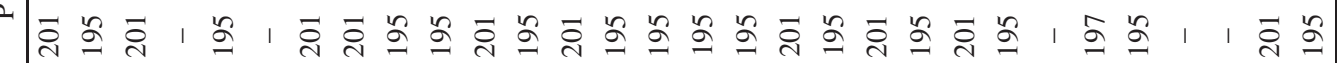

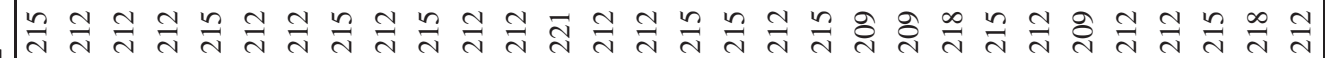
$\frac{2}{\mathscr{2}}$

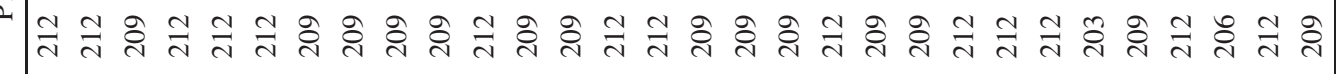

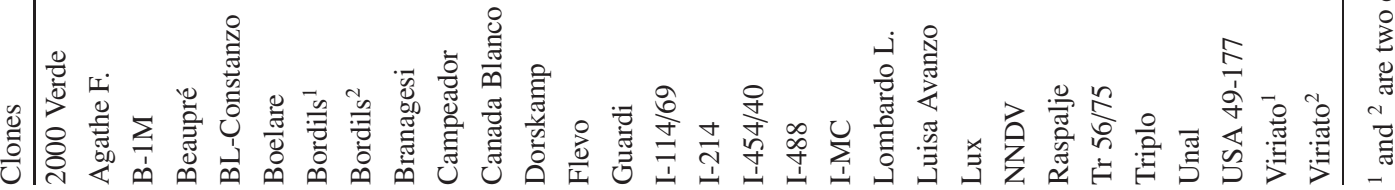




\subsection{Optimization of the genetic tool}

In order to reduce the time and the economic costs of the analysis, two sets of three SSR markers from the ten markers assayed have been multiplexed: ([PMGC14, WPMS20 and WPMS9] and [WPMS14, WPMS16 and WPMS18]). Reduced reaction volumes were used and several amplification programmes were tested for optimization. The final PCRs were carried out in a total volume of $10 \mu \mathrm{L}$, containing genomic DNA, $1 \times$ GeneAmp PCR Buffer II, $1.5 \mathrm{mM} \mathrm{MgCl} 2,0.2 \mathrm{mM}$ dNTPs mix, $0.4 \mu \mathrm{M}$ of each primer and $0.2 \mathrm{u}$ of Amplitaq ${ }^{\circledR}$ DNA polymerase (Applied Biosystems, Ca, USA). The optimized protocol includes one multiplex reaction following a slight modified programme from van der Schoot et al. [37] (reducing the annealing temperature to $55^{\circ} \mathrm{C}$ ), while the initial protocols have been kept for PTR2, PTR4 and for PTR7.

Stable and clear resolution amplification products were obtained with DNA both from wood and leaves using the same amplification conditions.

\section{DISCUSSION}

The results of our study clearly prove that microsatellite DNA markers can be an effective tool for genetic identification of commercial poplar clones of the Spanish National Catalogue. All the ten loci analysed were polymorphic and some of them were very informative for identification purposes. Only PTR4 locus, which showed good results in other studies [29], was not informative for the cultivars here considered, due to the lack of amplification on P. $\times$ interamericana clones. PTR4 was first described for $P$. tremuloides, a species reported to be genetically closer to $P$. deltoides, than to either $P$. nigra and $P$. trichocarpa, [7]. However, in our sample set, PTR4 has amplified as well P. nigra clones (Bordils ${ }^{1}$, Bordils ${ }^{2}$, Lombardo Leonés and $\operatorname{Tr} 56 / 75$ ) and P. deltoides (Lux and Viriato), but not $P$. trichocarpa parental in $P . \times$ interamericana group. This suggests that PTR4 does not amplify or show null alleles in both $P$. trichocarpa and $P$. deltoides species, although this latter could only be demonstrated by segregation analysis.

Of the 28 commercial clones in the Spanish National Catalogue, only 26 different combined genotypes have been found: two groups of clones were identical [I-214/Campeador] and [I$\mathrm{MC} / \mathrm{NNDv} / \mathrm{BL}-\mathrm{Costanzo}$, and two different genotypes were observed for the same clone name ("Bordils" and "Bordils"). The set of markers used showed a total $P I$ of $1.18 \times 10^{-9}$, meaning that the probability that two samples are different while showing the same genotypes is 1 out of 85000000000 approximately. This strongly supports the idea that the clones showing identical genotypes are, in fact, synonyms.

The genotypic similarity between [I-214/Campeador] and [I-MC/NNDv] pairs of clones is also supported by the results obtained by Alvárez et al. [1] using AFLP markers and the analogy between genotypes for [I-MC/BL-Costanzo] accessions described in Fossati et al. [15] is also in agreement with our results. For the clone "Bordils" two clearly different genotypes (in eight out of ten loci) have been observed in the samples analysed. Both of them were unique within the Spanish
Catalogue. These results are consistent with the origin of the clone, a selection from a natural P. nigra population (J. Rueda, personal communication), and a probable subsequent propagation of different individuals in the nurseries.

In this study, errors in labelling and management of plant material from the registered nurseries have been detected: (i) The genetic coincidence detected in one of the nurseries between "Triplo" and "Viriato" ${ }^{2}$ " clones, seems to be a management mistake affecting the mother trees, and limited to that particular nursery. (ii) The cross genotype between "2000 Verde" and "Guardi" clones from one of the registered nurseries is clearly a recent labelling mistake, because the new samples obtained and analysed from this nursery showed the genotypes found in original samples from the other nurseries. In this latter case, the mistake did not affect the mother trees.

Together, these results emphasize the need for a genetic identification of the poplar clones for authoritative certification and successful commercial management.

Time and costs of the analysis process were greatly reduced from those of the initial protocols, while maintaining stability and quality results (data not shown). Volume reactions and reactive amounts smaller than those used here yielded, in our hands, unstable results, due to difficulties in accurate measuring and handling. Good quality and stable amplification products were obtained from wood material, allowing the genetic analysis to be carried out at any time of the year. The accurate identification of clones of Spanish Catalogue can be achieved by using only three SSR markers: one multiplex reaction [WPMS14, WPMS16] and ORPM127, showing a $P I=2.4 \times 10^{-4}$.

The need to use molecular methods for the certification of plant material from vegetative propagation has been suggested by numerous institutions and research groups $[1,3,15,29,40]$. The European laws permit within the entire community the cultivation of poplar clones listed in the National Catalogue of any member country. Therefore it would be advisable to standardize molecular certification protocols for the genus Populus for the entire European Community.

Acknowledgements: The authors thank J. Rueda for technical and field advising; E. Notivol, C, Maestro, J. L. García, J.L. Peñuelas, H. Sixto and F. Camps for providing plant material; J.J Giraldo for helping with molecular characterization and C. Fischer for the English review. Thanks are extended to one anonymous reviewer and the editor for several comments that have improved the original manuscript. The work was supported by the project KPGN-541A (Autonomous Government of Castilla y León), and by a grant from the Council for the Environment (D.G. Natural Environment) from the same Autonomous Government.

\section{REFERENCES}

[1] Álvarez A., Cervera M.T., Agúndez D., Alba N., GonzálezAntoñanzas R., Zapater J.M., Grau J.M., Aplicación de la técnica AFLPs para la identificación de clones del Género Populus, I Simposio del Chopo, Zamora, 2001, pp. 381-389.

[2] Arévalo J., Avanzo E., Esnaola R., Fernández A., Lamoca C., Meneses J., Padró A., Rodríguez M., Ruiz de la Torre J., Saez A., Soria S., Los Chopos. Nociones de Populicultura, Madrid, 1992. 
[3] Bekkaoui F., Mann B., Schroeder B., Application of DNA markers for the identification and management of hybrid poplar accessions, Agrofor. Syst. 59 (2003) 53-59.

[4] Castiglione S., Wang G., Damiani G., Bandi C., Bisoffi S., Sala F., RAPD fingerprints for identification and taxonomic studies of elite poplar (Populus spp.) clones, Theor. Appl. Genet. 87 (1993) 54-59.

[5] Cavalli-Sforza L.L., Edwards A.W.F., Phylogenetic analysis: models and estimation procedures, Amer. J. Hum. Genet. 19 (1967) 233-257.

[6] Cervera M.T., Storme V., Ivens B., Gusmao J., Liu B.H., Hostyn V., van Stycken J., van Montagu M., Boerjan W., Dense genetic linkage maps of three Populus species (Populus deltoides, P. nigra and $P$. trichocarpa) based on AFLP and microsatellite markers, Genetics 158 (2001) 787-809.

[7] Cervera M.T., Storme V., Soto A., Ivens B., Van Montagu M., Rajora O.P., Boerjan W., Intraspecific and interspecific genetic and phylogenetic relationships in the genus Populus based on AFLP markers, Theor. Appl. Genet. 111 (2005) 1440-1456.

[8] Cervera M.T., Gusmao J., Steenackers M., van Gysel A., van Montagu M., Boerjan W., Application of AFLP-based molecular markers to breeding of Populus spp., Plant Growth Regul. 20 (1996) $47-52$.

[9] Dayanandan S., Rajora O.P., Bawa K.S., Isolation and characterization of microsatellites in trembling aspen (Populus tremuloides), Theor. Appl. Genet. 96 (1998) 950-956.

[10] DiFazio S.P., Measuring and modeling gene flow from hybrid poplar plantations: Implications for transgenic risk assessment, Ph. D. thesis, Department of Forest Science, Oregon State University, 2002, p. 229.

[11] Doyle J.J., Doyle J.L., Isolation of plant DNA from fresh tissue, Focus 12 (1990) 13-15.

[12] Fernández A., Hernaz G., Ramírez J., García-Caballero J.L., de Mier A., El Chopo (Populus sp.), 2004.

[13] Ferrazzini D., Monteleone I., Belletti P., Genetic variability and divergence among Italian populations of common ash (Fraxinus excelsior L.), Ann. For. Sci. 64 (2007) 159-168.

[14] Fossati T., Grassi F., Sala F., Castiglione S., Molecular analysis of natural populations of Populus nigra L. intermingled with cultivated hybrids, Mol. Ecol. 12 (2003) 2033-2043.

[15] Fossati T., Zapelli I., Bisoffi S., Micheletti A., Vietto L., Sala F., Castiglione S., Genetic relationships and clonal identity in a collection of commercially relevant poplar cultivars assessed by AFLP and SSR, Tree Genet. Genomes 1 (2005) 11-19.

[16] González-Martínez S.C., Gerber S., Cervera M.T., MartínezZapater J.M., Alía R., Gil L., Selfing and sibship structure in a twocohort stand of maritime pine (Pinus pinaster Ait.) using nuclear SSR markers, Ann. For. Sci. 60 (2003) 115-121.

[17] Grau J.M., González-Antoñanzas F., Montoto J.L., Populicultura intensiva, Madrid, 1996.

[18] IUPOV, Guidelines for the conduct of tests for distinctness, homogeneity and stability - Populus L., Geneva, Switzerland, 1981.

[19] JCyL, I Simposio del Chopo, Zamora, 2001, p. 434.

[20] Jianming G., Shougong Z., Liwang Q., Young Z., Chunguo W., Wenqin S., ISSR and AFLP identification and genetic relationships of Chinese elite accessions from the genus Populus, Ann. For. Sci. 63 (2006) 499-506.

[21] Langella O., Population 1.2.30beta. Logiciel de génétique des populations, in: Laboratoire Populations g.n.t.e.e.v., CNRS UPR 9034, Gif-sur-Yvette, http://wwwcnrs-gif.fr/pge/ (Ed.), 2002.
[22] Li J.-L., Deng H., Lai D.-B., Xu F., Chen J., Gao G., Recker R.R., Deng H.-W., Toward high-throughput genotyping: dynamic and automatic software for manipulating large-scale genotype data using fluorescently labeled dinucleotide markers, Genome Res. 11 (2001) $1304-1314$.

[23] Lin D., Hubbes M., Zsuffa L., Differentiation of poplar and willow clones using RAPD fingerprints, Tree Physiol. 14 (1994) 10971105.

[24] Nei M., Analysis of gene diversity in subdivided populations, Proc. Natl. Acad. Sci. USA 70 (1973) 3321-3323.

[25] Padró A., Orensanz J., El chopo y su cultivo, 1987.

[26] Paetkau D., Calvert W., Stirling I., Strobeck C., Microsatellite analysis of population structure in Canadian polar bears, Mol. Ecol. 4 (1995) 347-354.

[27] Rahman M.H., Dayanandan S., Rajora O.P., Microsatellite DNA markers in Populus tremuloides, Genome 43 (2000) 293-297.

[28] Rajora O.P., Genetic structure and identification of Populus deltoides clones based on allozymes, Genome 32 (1989) 440-448.

[29] Rajora O.P., Rahman M.H., Microsatellite DNA and RAPD fingerprinting, identification and genetic relationships of hybrid poplar (Populus $\times$ canadensis) cultivars, Theor. Appl. Genet. 106 (2003) 470-477.

[30] Rajora O.P., Zsuffa L., Multilocus genetic structure, characterization, and relationships of Populus $\times$ canadensis cultivars, Genome 32 (1989) 99-108.

[31] Sánchez N., Grau J.M., Bueno M.A., RAPD markers for the identification of Populus species, Silvae Genet. 47 (1998) 67-71.

[32] Scotti I., Paglia G., Magni F., Morgante M., Population genetics of Norway spruce (Picea abies Karst.) at regional scale: sensitivity of different microsatellite motif classes in detecting differentiation, Ann. For. Sci. 63 (2006) 485-491.

[33] Smulders M.J.M., van der Schoot J., Arens P., Vosman B., Trinucleotide repeat microsatellite markers for black poplar (Populus nigra L.), Mol. Ecol. Notes 1 (2001) 188-190.

[34] Tabberner H.E. Cottrell J.E., The use of PCR based DNA markers to study the paternity of poplar seedlings, For. Ecol. Manage.179 (2003) 363-376.

[35] Torres A.M., Weeden N.F., Martín A., Linkage among isozyme, RFLP and RAPD markers in Vicia faba, Theor. Appl. Genet. 93 (1993) 613-617.

[36] Tuskan G.A., Gunter L.E., Yang Z.K., Yin T., Sewell M.M., DiFazio S.P., Characterization of microsatellites revealed by genomic sequencing of Populus trichocarpa, Can. J. For. Res. 34 (2004) 85-93.

[37] Van der Schoot J., Pospisková M., Vosman B., Smulders M.J.M., Development and characterization of microsatellite markers in black poplar (Populus nigra L.), Theor. Appl. Genet. 101 (2000) 317-322.

[38] Wagner H.W., Sefc K.M., IDENTITY, Centre for Applied Genetics, University of Agricultural Science, Vienna, 1999.

[39] Weir B.S., Genetic Data Analysis II, Sinauer Associates Inc. Publishers, Sunderland, Massachusetts, 1996.

[40] Zhou C.J., Song H.Z., Li J.H., Sun J.W., Jin D.M., Zhang Q.W., Wang B., Evaluation of genetic diversity and germ plasm identification of 44 species, clones, and cultivars from 5 sections of the genus Populus based on amplified fragment length polymorphism analysis, Plant Mol. Biol. Rep. 23 (2005) 39-51. 